\title{
Verification of cyprid size as a tool in the identification of two European species of Chthamalus barnacles using mtDNA-RFLP analysis
}

\author{
Anne-Marie Power ${ }^{1, *}$, Sanit Piyapattanakorn ${ }^{2}$, Ruth M. O'Riordan ${ }^{1}$, Arati Iyengar ${ }^{2}$, \\ Alan A. Myers ${ }^{1}$, Stephen J. Hawkins ${ }^{2}$, Jane Delany ${ }^{1}$, David McGrath ${ }^{1,3}$, \\ Norman Maclean ${ }^{2}$

\footnotetext{
${ }^{1}$ Department of Zoology and Animal Ecology, University College Cork, Lee Maltings, Prospect Row, Cork City, Ireland ${ }^{2}$ Biodiversity and Ecology Division, School of Biological Sciences, University of Southampton, Biomedical Sciences Building, Bassett Crescent East, Southampton, SO16 7PX, United Kingdom

${ }^{3}$ Department of Life Sciences, Galway-Mayo Institute of Technology, Galway, Ireland
}

\begin{abstract}
Adult barnacles of Chthamalus stellatus and Chthamalus montagui were collected in August 1998, from Garrettstawn Co. Cork and Kilkee Co. Clare, in southwest and west Ireland, respectively. Attached cypris larvae were collected during the settlement season of $C$. stellatus and $C$. montagui, on 2 shores in Co. Cork and 1 shore on Clare Island. Co. Mayo in west Ireland. Cyprid collections were made during either August or September, in 1992, 1994 and 1998 and all cyprids were measured along their carapace length. Size-frequency histograms were produced for each sampling occasion. Total DNA was extracted and the COI-COII mitochondrial genes were PCR amplified, both from selected adults and cyprids of each species collected in 1998. Composite haplotypes, produced by digesting PCR products with the restriction endonucleases TaqI and Rsal, showed clear identification between the 2 species as adults and larvae. Of the 68 cyprids examined, those measuring $525 \mu \mathrm{m}$ and under were found to have RFLP profiles corresponding with C. montagui adults, while those of $550 \mu \mathrm{m}$ and larger were found to match $C$. stellatus adults. The findings verify previous length-frequency analysis. Carapace length is an important character in the identification of $C$. stellatus and $C$. montagui cyprids. The PCR primers developed during this study will also amplify DNA from 4 other species of acorn barnacle.
\end{abstract}

KEY WORDS: Chthamalus - Cyprids Identification - Carapace length - PCR-RFLP

\section{INTRODUCTION}

Two species of Chthamalus barnacles, C. stellatus and $C$. montagui, occur together in the intertidal zone on suitable shores from north Africa, along the Atlantic coast, to north Scotland and Ireland as well as in the English Channel and Mediterranean (Crisp et al. 1981). Distributions of the adults of these species may overlap considerably in terms of shore height and wave exposure. C. montagui is usually more common

·E-mail:am.power@ucc.ie in the upper barnacle zone, than it is lower down, where C. stellatus may be dominant (Crisp et al. 1981). C. stellatus is often abundant on wave-exposed coasts whereas $C$. montagui is more commonly found in embayed situations (Crisp et al. 1981). C. stellatus and C. montagui are similar in the northern and eastern limits of their geographic distributions and physiological adaptations (Crisp et al. 1981), as well as brooding cycles (Burrows et al. 1992, O'Riordan et al. 1992) and settlement seasons (Power et al. 1999). The processes controlling the distribution patterns of $C$. stellatus and C. montagui are as yet unknown. There are some differences between the 2 species in settled cyprid 
density relative to metamorph abundance (Power et al 1999) and larval development time (Burrows et al 1999). Studies which compare sympatric larval settlement in the field between these species have been hampered because, although minute structural differences in the cyprid carapace have been reported in $C$. stellatus and C. montagui (Jensen et al. 1994), no diagnostic tool for species identification as cyprids has been available

Carapace length has been suggested as a method of distinguishing between larvae of Chthamalus stellatus and C. montagui from field samples (Burrows 1988, Burrows et al. 1999, O'Riordan et al. 1999). The present work investigated size as a useful means of identifying C. stellatus and C. montagui cyprids from field samples collected at different dates in south and west Ireland. The development of a genetic marker allowed the identification of measured cyprids to be verified using mitochondrial DNA-RFLP (Restriction Fragment Length Polymorphism) analysis on identified adults compared with the cyprids of each species. Thus the extent of overlap in size between the cyprids of the 2 species could be determined.

\section{MATERIALS AND METHODS}

Sampling sites. Adult barnacles were collected from the middle and upper intertidal areas on 2 shores, in counties Cork (Garrettstown, 51 $38^{\prime} \mathrm{N}, 8^{\circ} 35^{\prime} \mathrm{W}$ ) and Clare (Kilkee, $52^{\circ} 41^{\prime} \mathrm{N}, 9^{\circ} 40^{\prime} \mathrm{W}$ ) Ireland during May 1998. Widely spaced (>150 km) shores were chosen in order to maximise the possibility of sampling genetically different populations of each species, should such differences exist. In the laboratory, adult barnacles of Chthamalus stellatus and C. montagui were identified and their somatic tissue dissected out, placed in $95 \%$ ethanol and stored at $-20^{\circ} \mathrm{C}$ for subsequent analysis.

Cyprids of Chthamalus stellatus and C. montagui were collected from pre-scraped $\left(5 \times 5 \mathrm{~cm}^{2}\right)$ quadrats between 16 August and 2 September 1998 from Gar-

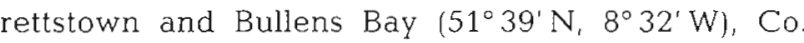
Cork, and in August 1992 and September 1994 from Portnakilly $\left(53^{\circ} 47^{\prime} \mathrm{N}, 9^{\circ} 59^{\prime} \mathrm{W}\right)$, Clare Island, Co. Mayo. All attached cyprids were removed using fine forceps and placed in 95\% ethanol and stored at $-20^{\circ} \mathrm{C}$. Cyprids were measured from the anterior to posterior margin of the carapace under a dissecting microscope (40× magnification). Length-frequency histograms of cyprid carapace length were produced using $25 \mu \mathrm{m}$ class intervals

Of the cyprids collected at Garrettstown 68 were chosen to be analysed genetically. 14 of the cyprids measured between 400 and $475 \mu \mathrm{m}$, and fell within the first modal length group, 23 were within the second modal length group (measuring between 550 and $700 \mu \mathrm{m}$ ) and 31 cyprids were chosen from size classes which were intermediate between the modal length groups (between 500 and $525 \mu \mathrm{m}$ ).

DNA extraction. The DNA extraction was carried out on adult barnacles using the modified CTAB protocol (Doyle \& Doyle 1991). Cypris larvae were washed once with sterile distilled water before DNA extraction, which was performed using standard phenol-chloroform procedure (Sambrook et al. 1989).

Genetic marker development. The PCR primers amplifying the Cytochrome Oxidase subunits I and II (COI-COII) region of mitochondrial DNA were developed, based on the COI-COIII DNA sequence of Balanus improvisus (Piyapattanakorn unpubl. data) aligned with the COI-COIII sequences already obtained for Drosophila yakuba, Apis mellifera and Daphnia pulex (Clary \& Wolstenholme 1985, Crozier \& Crozier 1993, Crease \& Little 1997, respectively). Highly conserved regions were identified within these sequences and a $B$. improvisus primer (BI-COI) was designed to allow more specific PCR amplification for barnacles. The COII-croz primer developed for A. mellifera (Crozier et al. 1989) was retained as the COII primer in this study since the mismatch within the sequences did not affect its specificity in $B$. improvisus. This set of primers produced specific PCR products $(\sim 1.3$ to $1.6 \mathrm{~kb})$ from various species of acorn barnacles (Elminius modestus, B. improvisus, Euraphia depressa, Tetraclita squamosa squamosa, Chthamalus stellatus and $C$. montagui) but not from Semibalanus balanoides.

A 10 l PCR reaction routinely used consisted of 5 to $10 \mathrm{ng}$ of extracted DNA, $1 \times$ PCR buffer (Advanced biotechnologies), $3.5 \mathrm{mM} \mathrm{MgCl}_{2}, 0.2 \mathrm{mM}$ of dNTPs, $0.1 \mu \mathrm{M}$ of each primer [BI-COI. (GAT ACC CGA GCT TAT TTI AC) and COII-Croz (CCA CAA ATT TCT GAA CAT TGA CC)], and 0.75 units of Taq polymerase (Advanced biotechnologies). The reaction was carried out as follows: $94^{\circ} \mathrm{C}$ for $2 \mathrm{~min}$ followed by 30 cycles of $94^{\circ} \mathrm{C}$ for $1 \mathrm{~min}, 54^{\circ} \mathrm{C}$ for $1 \mathrm{~min}$ and $72^{\circ} \mathrm{C}$ for 2 min with a final extension at $72^{\circ} \mathrm{C}$ for $7 \mathrm{~min}$, using a Hybaid Omnigene Thermocycler.

RFLP analysis. The $10 \mu$ restriction reaction contained $1 \times$ buffer (depending on the enzyme), 1 unit of restriction endonuclease, 300 to $500 \mathrm{ng}$ of PCR product $(\sim 4 \mu 1)$. The reaction was incubated for at least $2 \mathrm{~h}$ at $37^{\circ} \mathrm{C}$ for Rsal and at $65^{\circ} \mathrm{C}$ for Taql.

Electrophoresis. After the PCR product had been digested, the reactions were run on $1.5 \%(\mathrm{w} / \mathrm{v})$ agarose gel containing $0.2 \mathrm{mg} \mathrm{ml}^{-1}$ of Ethidium bromide at 80 volts and visualised on a UV transilluminator. The comparison of RFLP profiles (haplotypes) between gels was facilitated using a 100 bp DNA ladder (GibcoBRL). 


\section{RESULTS}

Measurements of all cyprids collected in 1992, 1994 and 1998 are shown in Fig. 1. Cyprids ranged in size from 350 to $750 \mu \mathrm{m}$ over the 3 yr sampled and the data exhibit bimodal size-frequency distributions in each case. The most frequently found size class in the first modal length group was 451 to $475 \mu \mathrm{m}$ on the 2 southwestern shores in 1998 and 476 to $500 \mu \mathrm{m}$ on the western shore in 1992 and 1994. The most common cyprid size class in the second modal group was less consistent, ranging between 576 and $650 \mu \mathrm{m}$, but with no consistent difference between southern and western shores.

Ten individual adults each of Chthamalus montagui and $C$. stellatus were initially used to screen with 7 restriction enzymes (RsaI, EcoRI, Hinfl, BfaI, Vsal, Ndell and TaqI). Six enzymes produced specific RFLP profiles, which can be used to identify C. montagui from C. stellatus and ECoRI showed no difference between the 2 chthamalids. However, only 2 enzymes (TaqI and Rsal) were selected for use in this study. Approximately 120 individual adults (30 individuals of each species from the Cork and Clare shores) were identified using composite haplotypes produced by TaqI and RsaI, respectively (Table 1). The common composite haplotype for C. stellatus was ED (70\%) and for C. montagui was AA (94\%). Although there were some rare haplotypes occurring with each restriction endonuclease, composite haplotypes between TaqI and RsaI showed clear identification between C. montagui and $C$. stellatus in each case (Table $1 \&$ Fig. 2).

All 68 cyprids were clearly identified by comparing cyprid haplotypes with those of the adults using the above genetic marker. There were 2 Rsal haplotypes, $C$ and $F$, found in cyprid samples which did not occur in adult samples (Table 1). However, the TaqI haplotypes of these cyprid samples were common haplotypes, $A$ and $E$, therefore the species of these cyprids were unambiguously identified (Table 1 \& Fig. 2).

Cyprid species, as determined by comparison of adult and larval RFLP profiles (composite haplotypes), and corresponding cyprid size are shown in Fig. 3.

\section{DISCUSSION}

This study relies on the analysis of mtDNA from Chthamalus stellatus and C. montagui, which unlike enzymes, can be obtained from alcohol-preserved material, to identify individuals of each species. The primers developed during the course of this study will also successfully amplify DNA from several other species of acorn barnacles. Previous work on the genetic profiles of C. stellatus and C. montagui focussed on different enzyme allozyme frequencies as an aid in their separation as adults (Dando et al. 1979) and newly metamorphosed individuals (Burrows 1988). Studies
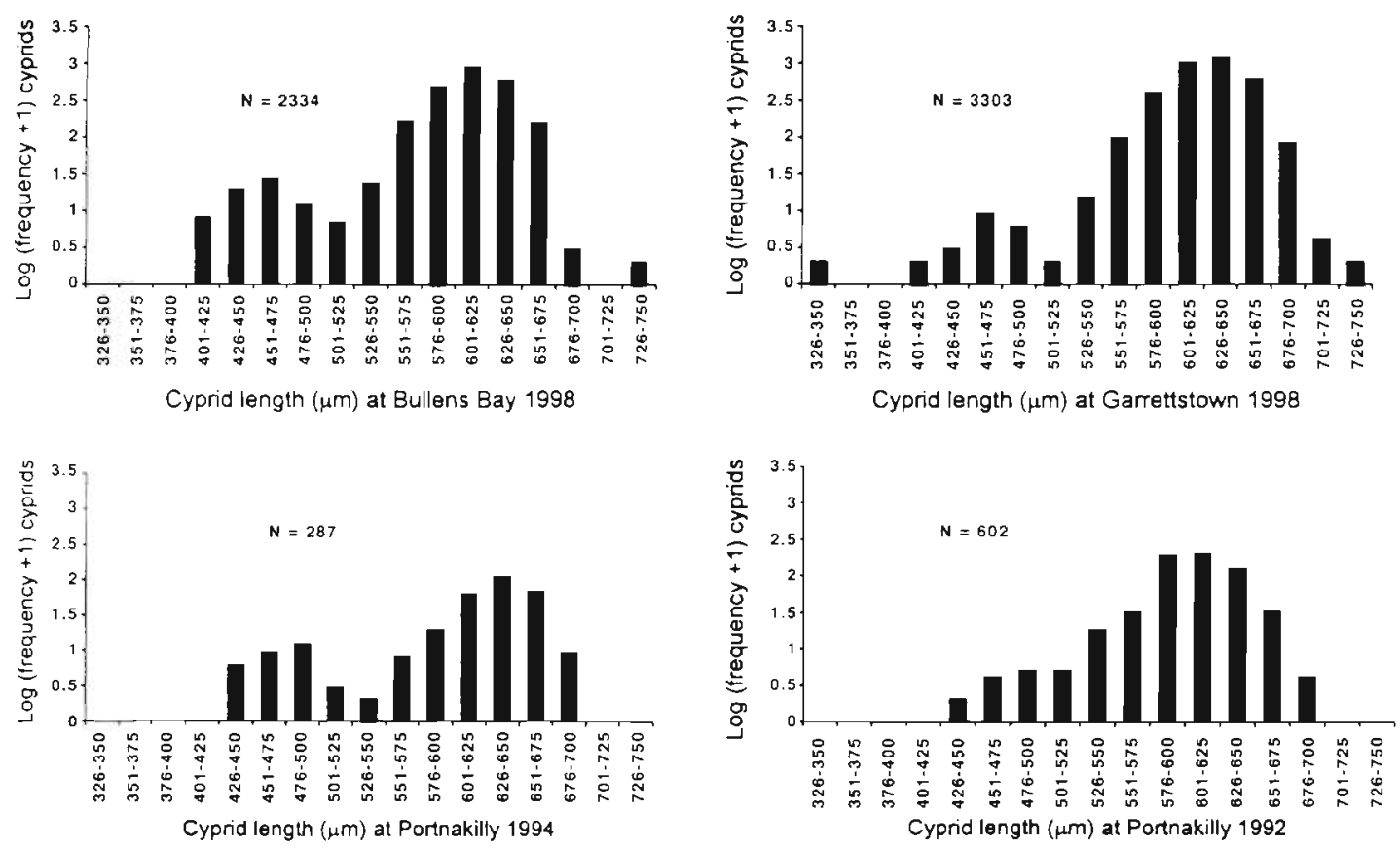

Fig. 1. Size-frequency of cyprids collected in 1998 at Bullens Bay and Garrettstown, southwest Ireland and in 1994 and 1992 at Portnakilly, west Ireland 
Table 1. Composite haplotypes of adults and larvae of Chthamalus montagui and C. stellatus. These are made up of haplotypes produced by RsaI (first letter) and TaqI (second letter). RsaI (A to F) and TaqI (A to G) haplotypes may be visualised in Fig. 2

\begin{tabular}{|c|c|c|c|c|c|}
\hline \multirow[t]{2}{*}{ Species } & \multirow[t]{2}{*}{ Composite haplotypes } & \multicolumn{2}{|c|}{ Adult frequency } & \multirow{2}{*}{$\begin{array}{l}\text { Cyprid frequency } \\
\text { Garrettstown }\end{array}$} & \multirow[t]{2}{*}{ Total frequency } \\
\hline & & Garrettstown & Kilkee & & \\
\hline \multirow[t]{8}{*}{ Chthamalus stellatus } & DE & 21 & 21 & 20 & 62 \\
\hline & FE & 0 & 0 & 1 & 1 \\
\hline & DD & 4 & 4 & 0 & 8 \\
\hline & DF & 2 & 1 & 1 & 4 \\
\hline & $D C$ & 2 & 2 & 1 & 5 \\
\hline & DG & 1 & 0 & 0 & 1 \\
\hline & $\mathrm{EC}$ & 0 & 1 & 0 & 1 \\
\hline & EG & 0 & 1 & 0 & 1 \\
\hline \multirow[t]{4}{*}{ Chthamalus montagui } & AA & 26 & 28 & 44 & 98 \\
\hline & $\mathrm{BA}$ & 2 & 0 & 0 & 2 \\
\hline & $\mathrm{CA}$ & 0 & 0 & 1 & 1 \\
\hline & $A B$ & 1 & 0 & 0 & 1 \\
\hline
\end{tabular}

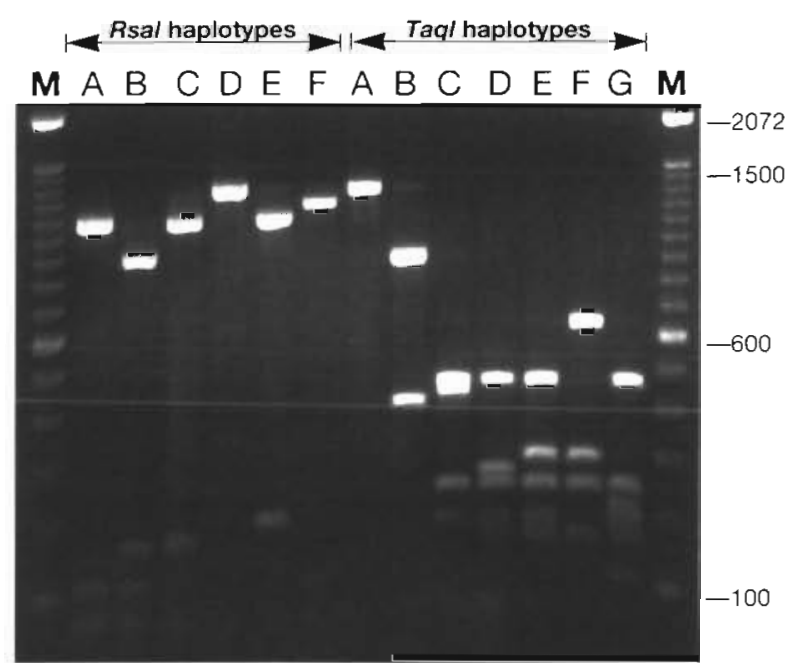

Fig. 2. Photograph of a $1.5 \%(\mathrm{w} / \mathrm{v})$ agarose gel showing the RFLP profiles of the COI-C:OII PCR product, after digestion with endonucleases Rsal and TaqI $[A, B, C, D, E, F \&$ G: different haplotypes produced with each restriction endonuclease, M: 100 bp DNA ladder (GibcoB̈RL)]

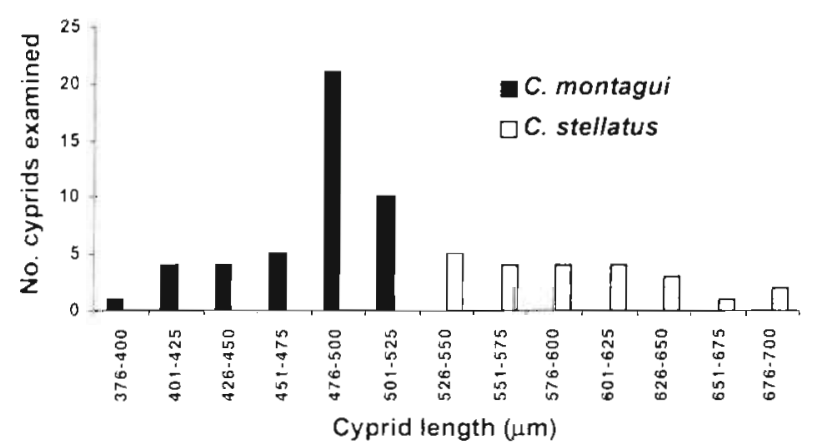

Fig 3. Sizes of genetically-identified cyprids collected at Garrettstown, southwest Ireland on the genetic variation within C. montagui (Dando \& Southward 1980, 1981, Pannacciulli et al. 1997) and $C$. stellatus populations (Pannacciulli et al. 1997) have also used allozymes.

A previous suggestion that size could be used as a tool to distinguish these species, was based on bimodally distributed carapace length data from August 1996 (O'Riordan et al. 1999) and comparisons of these lengths with laboratory-reared Chthamalus stellatus (Al-Yahya 1991) and C. montagui cyprids (Burrows 1988, Stone 1989, Whillis et al. 1990, Al-Yahya 1991, O'Riordan 1992, Jensen et al. 1994, Moyse et al. 1995). Cyprids measuring $483 \mu \mathrm{m}$ and smaller were suggested to be $C$. montagui and those of $563 \mu \mathrm{m}$ and larger to be $C$. stellatus (O'Riordan et al. 1999). Another indication that this might be a useful technique was reported by Burrows (1988), who extrapolated cyprid sizes of each species from their wild and laboratory-reared naupliar sizes at Plymouth, England (see also Burrows et al. 1999).

In the present study, the use of carapace length to differentiate between Chthamalus stellatus and C. montagui was verified using mtDNA-RFLP analysis on material collected at Garrettstown, southwest Ireland. The cypris larvae collected at Garrettstown and at Bullens Bay, Co. Cork in August/September 1998 demonstrated a bimodal size distribution similar to that reported by O'Riordan et al. (1999) from 6 shores (including Garrettstown and Bullens Bay) in Co. Cork during August 1996. Although the most frequent cyprid size class in the first modal group was slightly larger (by $25 \mu \mathrm{m}$ ) than that of O'Riordan et al. (1999), that of the second modal group had shifted to the right by at least the same amount, hence a ca $150 \mu \mathrm{m}$ separation was maintained between the size modes in both studies. In the present study, of the cyprids examined genetically lover the observed bimodal size-frequency 
range), all 14 cyprids of $475 \mu \mathrm{m}$ or less in carapace length were $C$. montagui, while all 23 cyprids measuring $550 \mu \mathrm{m}$ or more were C. stellatus. Cyprids of intermediate length between the 2 modal groups (infrequent lengths i.e. those between 476 and $525 \mu \mathrm{m}$ ) were of particular interest, because according to their size, they could have been either unusually small $C$. stellatus or unusually large C. montagui. Of the 31 cyprids analysed within this size range, all were $C$. montagui. Thus, from the material examined here, a very small but consistent size difference of $<25 \mu \mathrm{m}$ seems to separate the ranges in cyprid size of the 2 species in samples taken from southwest Ireland.

The length-frequency data of cyprids collected from Portnakilly in the west Ireland in 1992 and 1994 are also bimodal, although the modal length groups seem to be less distinct than on southwestern shores. Cyprid size (Pyefinch 1948, Crisp 1962) and embryo size (Crisp 1959, Barnes \& Barnes 1965) in field-collected Semibalanus balanoides, have been reported to vary with location and with latitude in particular, which has been linked to the rate at which the embryo develops (Barnes \& Barnes 1976). However, 'considerable variation' reported in cyprid length of $S$. balanoides at Millport in Scotland (Barnes 1953) is in fact less, at $10 \%$ of the modal length, than is reported here for Chthamalus cyprids (which vary between 21 and $38 \%$ of the modal length on the different sampling dates). Chthamalus stellatus nauplii from the north coast of France were larger than those at the Spanish coast and embryos developed faster at higher culture temperatures (Patel $\&$ Crisp 1960), but this work was carried out before $C$. montagui was separately identified by Southward (1976) and could have been a mixture of nauplii of both species. Cyprid size was the only character to distinguish between the larvae of Chthamalus fissus and Chthamalus dalli from California, the mean length of the former being slightly $(\sim 45 \mu \mathrm{m})$ larger (Miller et al. 1989). This is a much smaller separation than that observed between size modes of $C$. stellatus and $C$. montagui (minimum $100 \mu \mathrm{m}$ ) in the present study. In addition, no intraspecific differences were found in the naupliar sizes of laboratory-reared $C$. fissus and $C$. dalli when grown at low $\left(13^{\circ} \mathrm{C}\right)$ and high $\left(18^{\circ} \mathrm{C}\right)$ temperatures (Miller et al. 1989).

Further genetic confirmation is needed, as to the extent of overlap in cyprid size of Chthamalus stellatus and $C$. montagui at other latitudes, prior to using length as a general identification tool where the species occur sympatrically. Spatial and temporal variation in the sizes of field-collected cyprids of C. stellatus and $C$. montagui are currently being investigated from a number of European sites (O'Riordan 1999). Species of Chthamalus are frequently sympatric over part of their range (Southward 1976, Dando et al. 1979, Dando
\& Southward 1980,1981$)$ but studies on the settlement phase of sympatric C. stellatus and C. montagui populations are dependent upon a diagnostic tool such as carapace length to reliably and quickly identify large numbers of cyprids from field samples along the species ranges.

Acknowledgements. We are grateful to the European Community who funded both the work in Cork and travel costs between Cork and Southampton, under the MAST-3 programme, contract no. MAS3-CT95-0012. Also to the Thai Government for supporting the genetics work in Southampton and to the Royal Irish Academy for funding samples collected as part of the New Survey of Clare Island. Finally, we wish to thank Prof Tom Cross and Dr D. K. A. Barnes for useful comments on the manuscript.

\section{LITERATURE CITED}

Al-Yahya HAH (1991) Studies on cirripede larvae with special reference to external features of cyprids from five families. PhD thesis, University of Wales, Swansea

Barnes H (1953) Size variations in the cyprids of some common barnacles. J Mar Biol Assoc UK 32:297-304

Barnes H, Barnes M (1965) Egg size, nauplius size, and their variation with local, geographical, and specific factors in some common cirripedes. J Anim Ecol 34:391-402

Barnes $H$, Barnes $M$ (1976) The rate of development of the embryos of Balanus balaniodes (L.) from a number of European and American populations and the designation of local races. J Exp Mar Biol Ecol 24:251-269

Burrows MT (1988) The comparative biology of Chthamalus stellatus (Poli) and Chthamalus montagui Southward. PhD thesis, University of Manchester

Burrows MT, Hawkins SJ, Southward AJ (1992) A comparison of reproduction in co-occurring chthamalid barnacles, Chthamalus stellatus (Poli) and Chthamalus montagui Southward. J Exp Mar Biol Ecol 160:229-249

Burrows MT, Hawkins SJ, Southward AJ (1999) Larval development of the intertidal barnacles Chthamalus stellatus and Chthamalus montagui. J Mar Biol Assoc UK 79 : 93-101

Clary DO, Wolstenholme DR (1985) The mitochondrial DNA molecule of Drosophila yakuba: nucleotide sequence, gene organisation, and genetic code. J Mol Evol 22: $252-271$

Crease TJ, Little TJ (1997) Partial sequence of the mitochondrial genome of the crustacean, Daphnia pulex. Curr Genet 31:48-54

Crisp DJ (1959) Factors influencing the time of breeding of Balanus balanoides. Oikos 10:275-289

Crisp DJ (1962) The planktonic stages of the cirripedia Balanus balanoides (L.) and Balanus balanus (L.) from north temperate waters. Crustaceana 3:207-221

Crisp DJ, Southward AJ, Southward EC (1981) On the distribution of the intertidal barnacles Chthamalus stellatus, Chthamalus montagui and Euraphia depressa. J Mar Biol Assoc UK 61:359-380

Crozier RH, Crozier YC (1993) The mitochondrial genome of the honeybee Apis mellifera: complete sequence and gene organisation. Genetics 133:97-117

Crozier RH, Crozier YC, Mackinlay, AG (1989) The CO-I and CO-II region of honeybee mitochondrial DNA: evidence 
for variation in insect mitochondrial evolution rates. $\mathrm{Mol}$ Biol Evol 6:399-411

Dando PR, Southward AJ (1980) A new species of Chthamalus (Crustacea: Cirripedia) characterised by enzyme electrophoresis and shell morphology: with a revision of other species of Chthamalus from the western shores of the Atlantic. J Mar Biol Assoc UK 60:787-831

Dando PR, Southward AJ (1981) Existence of 'Atlantic' and 'Mediterranean' forms of Chthamalus montagui (Crustacea: Cirripedia) in the western Mediterranean. Mar Biol Lett 2:239-248

Dando PR, Southward AJ, Crisp DJ (1979) Enzyme variation in Chthamalus stellatus and Chthamalus montagui (Crustacea: Cirripedia); evidence for the presence of C. montagui in the Adriatic. J Mar Biol Assoc UK 59:307-320

Doyle JJ, Doyle JL (1991) Isolation of Plant DNA from fresh tissue. Focus 12:13-15

Jensen PG. Moyse J, Høeg J, Al-Yahya, H (1994) Comparative SEM studies of lattice organs: putative sensory structures on the carapace of larvae from Ascothoracida and Cirripedia (Crustacea Maxillopoda Thecostraca). Acta Zool 75:125-142

Miller KM, Blower SM, Hedgecock D, Roughgarden J (1989) Comparison of larval and adult stages of Chthamalus dalli and Chthamalus fissus (Cirripedia: Thoracica). J Crustac Biol 9:242-256

Moyse J, Høeg JT, Jensen PG, Al-Yahya HAH (1995) Attachment organs in cypris larvae: using scanning electron microscopy. In. Schram ER, Høeg JT (eds) New frontiers in barnacle evolution. AA Balkema, Rotterdam, p 153-177

O'Riordan RM (1992) Reproduction and recruitment of two intertidal chthamalid barnacles. PhD thesis, University College Cork

Editorial responsibility: Otto Kinne (Editor),

Oldendorf/Luhe, Germany
O'Riordan RM, Myers AA, Cross TF (1992) Brooding in the intertidal barnacles Chthamalus stellatus (Poli) and Chthamalus montagui Southward in south-western Ireland. J Exp Mar Biol Ecol 164:135-145

O'Riordan RM, Myers AA, McGrath D, Delany J, Power AM (1999) The sizes at settlement in natural populations of cyprids of Chthamalus montagui and C. stellatus. J Mar Biol Assoc UK 79:365-366

Pannacciulli F, Bishop JDD. Hawkins SJ (1997) Genetic structure of populations of two species of Chthamalus (Crustacea: Cirripedia) in the north-east Atlantic and Mediterranean. Mar Biol 128:73-82

Patel B. Crisp DJ (1960) Rates of development of the embryos of several species of barnacles. Physiol Zool 33:104-119

Power AM, Delany J, Myers AA, O'Riordan RM, McGrath $D$ (1999) Prolonged settlement and prediction of recruitment in two sympatric intertidal Chthamalus species from south-west Ireland. J Mar Biol Assoc UK 79: 941-943

Pyefinch KA (1948) Notes on the biology of Cirripedes. J Mar Biol Assoc UK 27:464-507

Sambrook J, Fritsch EF, Maniatis T (1989) Molecular cloning: a laboratory manual, 2nd edn. Cold Spring Harbor Press, New York

Southward AJ (1976) On the taxonomic status of Chthamalus stellatus (Cirripedia) in the north-east Atlantic region: with a key to the common intertidal barnacles of Britain. J Mar Biol Assoc UK 56:1007-1028

Stone CT (1989) A comparison of algal diets for cirripede nauplij. J Exp Mar Biol Ecol 132:17-40

Whillis JA, Yule AB, Crisp DJ (1990) Settlement of Chthamalus montagui Southward cyprids on barnacle arthropodin. Biofouling 2:95-99

Submitted: May 4, 1999; Accepted: July 16, 1999

Proofs received from author(s): December 16, 1999 